\title{
The decision to moonlight: does second job holding by the self- employed and employed differ?
}

\author{
Andrew Atherton ${ }^{\mathrm{a}}$, João R. Faria ${ }^{\mathrm{b}}$, Daniel Wheatleyc, Dongxu Wu ${ }^{\mathrm{d}}$ and \\ Zhongmin $\mathrm{Wu}^{\mathrm{c}}{ }^{*}$ \\ ${ }^{\text {a }}$ Lancaster University, UK \\ ${ }^{\mathrm{b}}$ COLA, University of Texas at El Paso, USA \\ ${ }^{\mathrm{c}}$ Nottingham Business School, Nottingham Trent University, UK \\ ${ }^{\mathrm{d}}$ Fitzwilliam College, University of Cambridge, UK
}

\begin{abstract}
This paper considers drivers of second job holding amongst the selfemployed in comparison with the employed. Econometric analysis of panel data explores whether the self-employed are more or less likely to take on a second job when already running their own business, than their employed counterparts. The findings contribute to the literature through identification of a need-based variable difficulty in meeting housing costs - as a key driver of movements from selfemployment to hybrid entrepreneurship. Findings, further, identify different patterns of second job holding by gender, particularly amongst self-employed individuals.
\end{abstract}

Key Words: Second job holding; self-employment; financial hardship; gender; panel data. JEL classification: J22, L26.

\footnotetext{
* Corresponding author, Dr Zhongmin Wu, Reader in Economics, Nottingham Business School, Nottingham Trent University, email: zhongmin.wu@ntu.ac.uk.
} 


\section{Introduction}

This paper investigates the rationale for the self-employed to hold a second job, and whether this form of moonlighting differs from those in employment. Although there is growing recognition that individuals can run their own business and concurrently hold a second job as an employee, the focus of this literature has been on part-time working as a means of entry into self-employment (Burke et al, 2008; Folta et al, 2010). This paper extends the literature, contributing to our understanding of self-employment by presenting evidence that 'hybrid entrepreneurship', i.e. the holding of paid employment at the same time as owning and running a business, occurs not only as an entry step into self-employment, as has been proposed previously (Folta et al, 2010), but also as a method of sustaining self-employment. Moreover, the paper contributes to our understanding of the relationship between financial hardship - using a need-based variable (difficulty in meeting housing costs) - and second job holding, and considers the role of household factors in patterns of second job holding among the employed and self-employed.

Self-employment can offer significant flexibility and work autonomy, and so represents an opportunity for a different way of working to paid employment (Fraser and Gold, 2001). However, self-employment also generates uncertainty, stress and anxiety for entrepreneurs who have responsibility for ensuring the survival and success of their business (Fenwick, 2006). Movements between employment and selfemployment may be motivated by 'entrepreneurial pull' or 'unemployment push', with the latter estimated as accounting for up to $48 \%$ of movements into selfemployment (Dawson and Henley, 2012). In recent years casualization of the workforce, and the replacement of secure paid employment with short-term contract work (Raess and Burgoon, 2015, 95-6), has resulted in self-employment offering the 
only viable option to work for some individuals. Meanwhile, those already selfemployed have faced particular challenges since the 2008 financial crisis, which created particular short-term pressure on the financial viability of many entrepreneurs’ businesses including limiting access to credit (Cowling et al, 2012).

In response to these pressures the self-employed may "moonlight" ${ }^{1}$ by taking on a second job (Renna, 2006). Taking on paid employment alongside selfemployment can be driven by a range of factors. Second job holding may reflect low capitalization of the entrepreneur's business, a particular feature of smaller enterprises, and particularly women-owned businesses (Hundley, 2001). Moonlighting may occur when entrepreneurs wish to retain links with previous employers or clients, especially when self-employment is viewed as a career 'stage' rather than a permanent commitment (Hytti, 2010). When wider macro-economic conditions place pressures on smaller enterprises, as has been the case in recent years in the OECD economies, second job holding can supplement reduced income from the owner-managed business (Flandez, 2009). However, owner-managers would rationally only take on a second job with an expectation that this is an interim arrangement until returns improve from self-employment.

In this paper, the multiple job holding behaviours of self-employed individuals and employees are compared using data from waves 1-18 (1991-2009) of the British Household Panel Survey (BHPS). ${ }^{2}$ The UK economy offers an interesting empirical focus as it has adopted a liberal employment policy, with growing flexibility, and

\footnotetext{
${ }^{1}$ Moonlighting is used interchangeably with the term second job holding in this paper, and therefore signifies taking on a second job of employed labour. It does not signify undertaking self-employment or business start-up while holding a main job as a paid employee.

${ }^{2}$ From its inception the BHPS included samples from England, Scotland and Wales, and from 2001 a sample from Northern Ireland was added, providing a sample of around 10,000 households from across the UK (BHPS, 2009).
} 
uncertainty, characterising paid work (Lewis and Campbell, 2008). Self-employment has risen over the period analysed, to approximately 13.5\% of the workforce in 2009. At the same time, income from self-employment has declined significantly in recent years (ONS, 2014). Estimates from the end of 2009 report approximately $4 \%$ of the UK workforce holding a second job, with marginally more women reporting dual job holding (Labour Force Survey, 2009).

\section{Second job holding}

\subsection{Theories of second job holding applied to the employed and self-employed}

There are several theoretical frameworks that seek to explain why individuals take on multiple jobs, including the: (1) main job hour constraint; (2) heterogeneous jobs, and (3) main job insecurity models.

The main job hour constraint model

The main job hour constraint model (Shishko and Rostker, 1976; Paxson and Sicherman, 1996) suggests that employees take on a second job when they would like to work more hours at their prevailing primary wage rate, but these hours are not available through the primary job. In this case, the individual will take a second job when the wage rate is at or above the second job reservation wage (see Shishko and Rostker, 1976). Existing literature is indicative of the presence of constrained hours among employees. For example, evidence from the UK Labour Force Survey finds $12.2 \%$ of employees working part-time as a result of a lack of full-time opportunities (Green and Livanos, 2015). However, while this model may apply to employees, it is not clear it is relevant for the self-employed. It can be argued that, in principle, the self-employed can choose their working hours, and so would have no incentive to 
take on another job as they can increase the hours worked in their primary occupation. The main job hour constraint model therefore appears to apply to employees, but not to the self-employed.

It is conceivable that the self-employed may take on a second job with higher wage rates should there be diminishing marginal returns from additional hours of selfemployment. However, this appears to be unlikely because hours worked in selfemployment tend not to be varied at the discretion of the worker. Pressures to build and manage a business, including ensuring its survival, typically require substantial time-inputs, which need to be undertaken by the self-employed individual. Conversely, there will be limits to the number of additional hours that could be worked when self-employment becomes a means of achieving greater flexibility in work patterns, in order to balance work and household responsibilities, which is a common driver of self-employment (Mallon and Cohen, 2001). As a result, it is implausible that a self-employed individual would seek further hours of employment in a second job, either because they are already working extensive hours (Meier and Stutzer, 2006), or they are working shorter hours to balance other responsibilities.

The heterogeneous jobs model

The heterogeneous jobs model (Conway and Kimmel, 1998) proposes that employees become less satisfied when working more hours in a single job dominated by standard or mundane tasks. Diversity of tasks and challenges increases job satisfaction and so can incentivise longer working hours. In highly skilled roles this may be achieved through single job holding where adequate levels of autonomy and control are encountered, which have been shown to increase work satisfaction (Eckersley, 2007) and reduce work-related stress (Kalleberg et al, 2009). An 
employed individual with a variable first job would be less likely to take on a second job than an employee with a relatively mundane first job. A lack of task diversity may act as a rationale for movements between jobs or multiple job holding. Individuals with relatively mundane first jobs are more likely to take a second job when this offers greater variety, provided they have the skills and experience to secure a more variable job. More often these jobs are attractive, and so subject to greater competition.

Self-employment often involves considerable autonomy, task variety and challenge associated with building and managing a business, although this does vary in different occupations (Fraser and Gold, 2001). As such, job heterogeneity is a central feature of self-employment, suppressing a desire to seek task variety through second job holding. It follows, then, that for most self-employed individuals they would only seek additional employment when job heterogeneity is greater than in self-employment. Job heterogeneity appears to explain moonlighting by employed individuals, but does not appear to explain second job holding amongst the selfemployed, although this may be relevant among some of those constrained into selfemployment as a result of the casualization of work.

\section{The main job insecurity model}

The main job insecurity model suggests an individual may take on a second job if they believe that their primary job is at risk of termination (Bell et al., 1997). Second job holding provides some assurance against risk of termination and loss of income. Second job holding also allows individuals to explore alternative employment (Alden, 1982). Panos et al (2009) found that moonlighting increases the probability of securing a new job and decreases the probability of becoming 
unemployed or inactive should the main job terminate. Main job insecurity may encourage individuals to explore business start-up as an alternative to losing their main job, and so may represent a route into self-employment (Folta et al., 2010). In addition, second job holding may represent a move away from self-employment, which is a risky, and hence uncertain, activity, when the second job is secured in order to move to employment. These possibilities therefore suggest that main job security may lead to second job holding by both the employed and self-employed, but that for the self-employed in particular this state is likely to be short-lived as individuals either commit to entrepreneurship or quit in favour of paid employment.

Three mainstream models of second job holding do not adequately explain the rationale for the self-employed to hold a second job, even though they offer credible explanations of second job holding in some regards. This paper seeks to extend the literature through identification of an alternative explanation for second job holding, predicated on the view that financial pressures are a primary incentive for second job holding (Bell et al, 1997; Wu et al, 2009).

\subsection{Financial pressures as a driver of second job holding by the self-employed}

Self-employment is likely to generate utility, producing non-financial benefits, even if the financial returns from this choice of work are not high (Barton, 2000; Benz, 2009; Dawson and Henley, 2013; Fenwick, 2006; Blanchflower, 2000). When the amenity of self-employment is high, but the financial returns are not, there is a greater propensity to take on a second job, in order to fund continuation of the main form of work (Lundborg, 1995). Although not all self-employed individuals run businesses that provide non-financial benefits but insufficient income to continue 
without second job holding, a significant proportion do (Henley, 2007). These selfemployed entrepreneurs are more likely to take on a second job to supplement income from the primary self-employment. Moonlighting is likely to be a feature of selfemployment for individuals who want to continue to run their own business, but cannot generate sufficient income from their venture. Wu et al. (2009) find that "The incentive for them to moonlight therefore appears to stem from financial pressures and the desire to raise, or secure, standards of living with multiple job holding as one dimension to achieving such goals".

Second job holding may also be a temporary feature of self-employment in order to compensate for falls in, and volatility in streams of, income from selfemployment (Ceritoglu, 2013; Guariglia and Kim, 2004). Moonlighting is more likely during economic downturns, less so when macro-economic conditions improve (Amuedo-Dorantes and Kimmel, 2009; Flandez, 2009). In these cases of selfemployment, moonlighting is a means of overcoming periods of lower demand. In all of these cases, insufficient income from self-employment drives second job holding, to enable retention of some of the non-financial 'lifestyle' benefits of selfemployment even when financial returns are insufficient (Livanos and Zangelidis, 2012; Renna, 2006, 584). Whether insufficient income from self-employment is temporary or a feature of this form of entrepreneurship, the financial pressures that arise drive entrepreneurs to supplement their income through a second job. This may be to secure a sufficient standard of living, or to generate cash flow to continue the business (Dickey et al, 2011). Insufficient income from the main job is also likely to encourage second job holding by people who are employed, even when wages from moonlighting are lower than the main job (Kimmel and Conway, 2001). 
These conclusions suggest different reasons for moonlighting between employees and the self-employed. For employees, standard theories of second job holding apply. For at least some self-employed, the rationale for moonlighting appears to be to sustain a non-viable business - either temporarily or as part of a longer-term strategy - by supplementing income from this source with wages from a second job. Both considerations establish a case for moonlighting whether employed or self-employed. However, the motivations for moonlighting differ.

\subsection{Working hours and second job holding}

The distinct motivations for moonlighting between the employed and selfemployed may be manifest in differences in moonlighting hours. Longer working hours are often a feature of self-employment, in part driven the lifestyle benefits derived from this form of employment, although hours differ by gender as a result of the varying drivers of self-employment (Lee et al, 2007, 112-13; Hundley, 2001). Longer second job hours may similarly be manifest, as commitment to a business that cannot be sustained without supplementary earnings indicates that an entrepreneur is willing to forego increased leisure time by taking on a second job to support their business, rather than moving from self-employment to employment. The implied costs of these sacrifices appear considerably higher than for employees who seek additional hours to top up income, undertake more interesting work, or have insecure main jobs. Moreover, the financial requirements to sustain a financially non-viable business are likely to be greater than the search for job security or additional hours that drive moonlighting by employees. This leads to our first proposition:

Proposition 1: Self-employed second job holders are likely to work longer hours when moonlighting than employees. 


\subsection{Household pressures as a driver of second job holding}

In some cases individuals become self-employed in order to have more flexibility in their work patterns and hours. High-pressure, high income careers may be traded for a less intensive work pattern offering improved balance between work and leisure or household activities through self-employment (Morrison, 2006; Drew, 1998). However, greater work flexibility also reduces personal income. Selfemployment may also represent a way of avoiding career stagnation when flexibility becomes necessity as a result of increased household responsibilities.

Dependent children are likely to act as a key driver for flexibility among women in particular (Schmid, 2010; Wheatley and Wu, 2014). However, the burden of household responsibilities and childcare can limit the extent to which individuals can commit to entrepreneurial activity, reducing income and the intensity of work effort (Hundley, 2001). Partly because of this, self-employed individuals who are home-based are more likely to hold second jobs that supplement income from their business (Mason et al, 2011; Stanworth and Stanworth, 1995). This leads to a second proposition, which qualifies the first proposition above:

Proposition 2: Women are more likely than men to seek out self-employment to generate greater flexibility in work (including hours, location) because of non-work related tasks, but for some women this route into self-employment necessitates second job holding.

\subsection{Housing costs as a driver of second job holding}

Housing costs represent the most significant expenditure for most households (Stone, 2006), and these costs are likely to be relatively more significant to mortgage 
holders than renters (Deidda, 2015). For employees second job holding is one means of ensuring that core recurrent household costs are met (Livanos and Zangelidis, 2012). Similarly, the self-employed are likely to consider housing costs as one of the most essential expenditures they would need to cover from moonlighting, if they are to maintain standards of living when income from their business is insufficient (Dickey et al., 2011). Where financial pressure is faced due to insufficient income, among both the self-employed and employed, this may act as a driver for second job holding (Wu et al, 2009; Kimmel and Conway, 2001). For both the self-employed and employed housing costs are, therefore, likely to have a significant effect on the propensity to hold a second job. This is consistent with the earlier review of mainstream theories of second job holding, and our formulation that entrepreneurs moonlight in order to stay in self-employment even when facing financial hardship, rather than seeking movement into full-time employment, because of the associated non-financial benefits (Livanos and Zangelidis, 2012; Renna, 2006, 584). This gives us our third proposition (a theoretical case supporting proposition 3 is outlined in the appendix providing further justification for this proposition):

Proposition 3: Housing costs are likely to be positively and significantly correlated with second job holding for both the employed and self-employed.

\section{Data and method}

The BHPS provides a robust empirical basis for the analysis conducted. It was designed using a stratified random sampling method as an annual survey of each adult member (aged 16 years and over) of a nationally representative sample of households from England, Scotland and Wales, with a Northern Ireland sample added from 2001 (varying from 5,000 to 10,000 households throughout the life of the survey). 
Respondents were successively re-interviewed and, where leaving their original household, all adult members of their new household were interviewed (BHPS, 2009). The focus of this paper is on economically active individuals aged 16 to 65 years. The BHPS includes a range of variables which provide insight into the self-employed.

Employment status is self-assessed in the BHPS questionnaire, based on responses to the question: “Are you an employee or self-employed?” In addition, the BHPS tests for second job holding, asking: "Do you currently earn any money from (a second job) odd jobs or from work that you might do from time to time (apart from your main job)?” As a result, the data can be used for testing moonlighting, as defined by second job holding, for both the self-employed and employees. As well as determining whether or not survey respondents moonlight, the analysis examines the extent to which such activities are undertaken. Tobit models are used to consider the question: "How many hours do you usually work a month in your second/odd job(s), excluding meal breaks but including any overtime you might do?” This allows determination of the scale, and hence importance, of second job holding. The empirical analysis therefore captures both the decision to take a second job and the number of hours worked, 'J2hours'. These models compare second job holding among four groups: (1) employed men; (2) self-employed men; (3) employed women, and; (4) self-employed women. Results of the Tobit models are consistent with, and without, controls for the two dummies (year and region), and with the Logit model, Probit model and Fixed Effect model (available upon request).

Particular emphasis is placed on variables focusing on financial hardship. Existing research has struggled to identify a variable that empirically captures economic necessity as a driver of second job holding among the self-employed. Some past research has used a mortgage variable, on the basis that the cost of repaying and 
servicing this primary debt will significantly affect household incomes net of major outgoings such as house purchase (Brown et al., 2005). If mortgages are high and take up a large proportion of first job income, individuals are more likely to look for a second job. This is, however, an imperfect variable, as people who have mortgages do not necessarily struggle in making mortgage payments. The BHPS enables analysis of both mortgage holding and whether housing costs create financial hardship for selfemployed and employed individuals. The Tobit models include 'Mortgaged' as a binary variable determining whether the respondent has a mortgage or not. The question that sufficiently captures difficulties in meeting housing payments, is a focus variable in this paper, reflecting responses to the question: "In the last twelve months would you say you have had any difficulties paying for your accommodation?” This provides a binary measure, 'Difficulty pay', of whether the respondent is experiencing problems in paying for their housing

Additional variables are included, selected on the basis of findings presented in the existing literature (e.g. Dickey et al., 2011; Folta et al., 2010; Hundley, 2001; Kimmel and Conway, 2001; Renna, 2006), to provide insight into factors affecting second job holding, including: income (using a measure of annual labour income); whether the individual is married; number of children; age; health status over the last 12 months compared to people of their own age; level of education (using the International Standard Classification of Education (ISCED)); occupation (using the UK Standard Occupational Classification major groups); work location (using categories defined in the BHPS which differ for employees and the self-employed); partner employment variables, specifically whether partner is in work, their working hours and their income; and region of residence (using UK Government Office Regions). 


\section{Empirical analysis}

Approximately $12.3 \%$ of the BHPS sample report self-employment over the period 1991-2009. Rates are higher among men (17.5\% on average) than women (6.9\%). Consistent proportions (9\%) of both self-employed men and women report holding a second job. Consistent with existing literature (Lee et al, 2007; Hundley, 2001), working hours among the self-employed are much lengthier among men (45.3 hours per week) than women (30.6 hours). Among those who moonlight, hours of self-employment (main job equivalent) are lower, but remain lengthy for men at around 40 hours. Figure 1, further, indicates that self-employed men worked considerably more hours in their second job per month than moonlighting male employees.

Figure 1: Average hours worked per month in second job by men (BHPS)

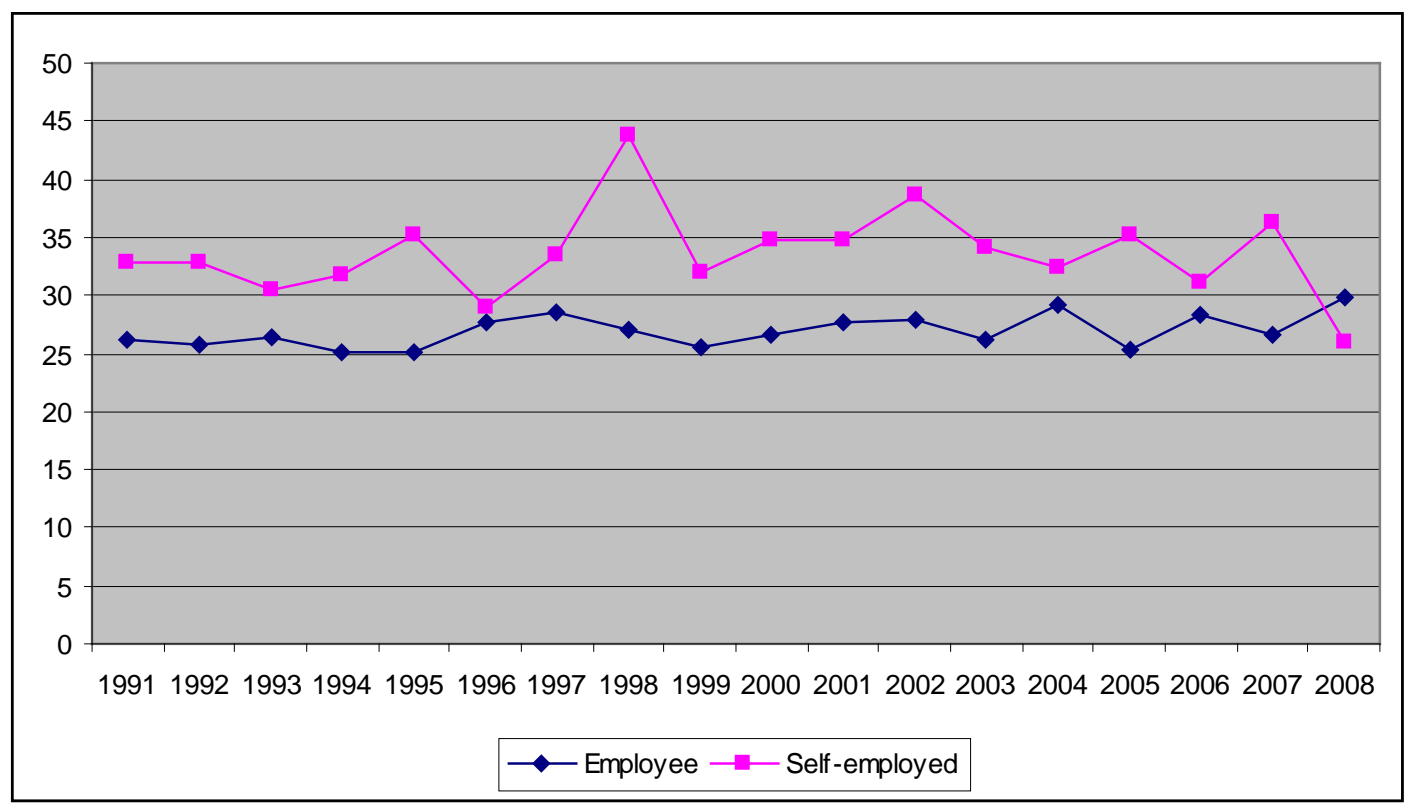


Figure 2: Average hours worked per month in second job by women (BHPS)

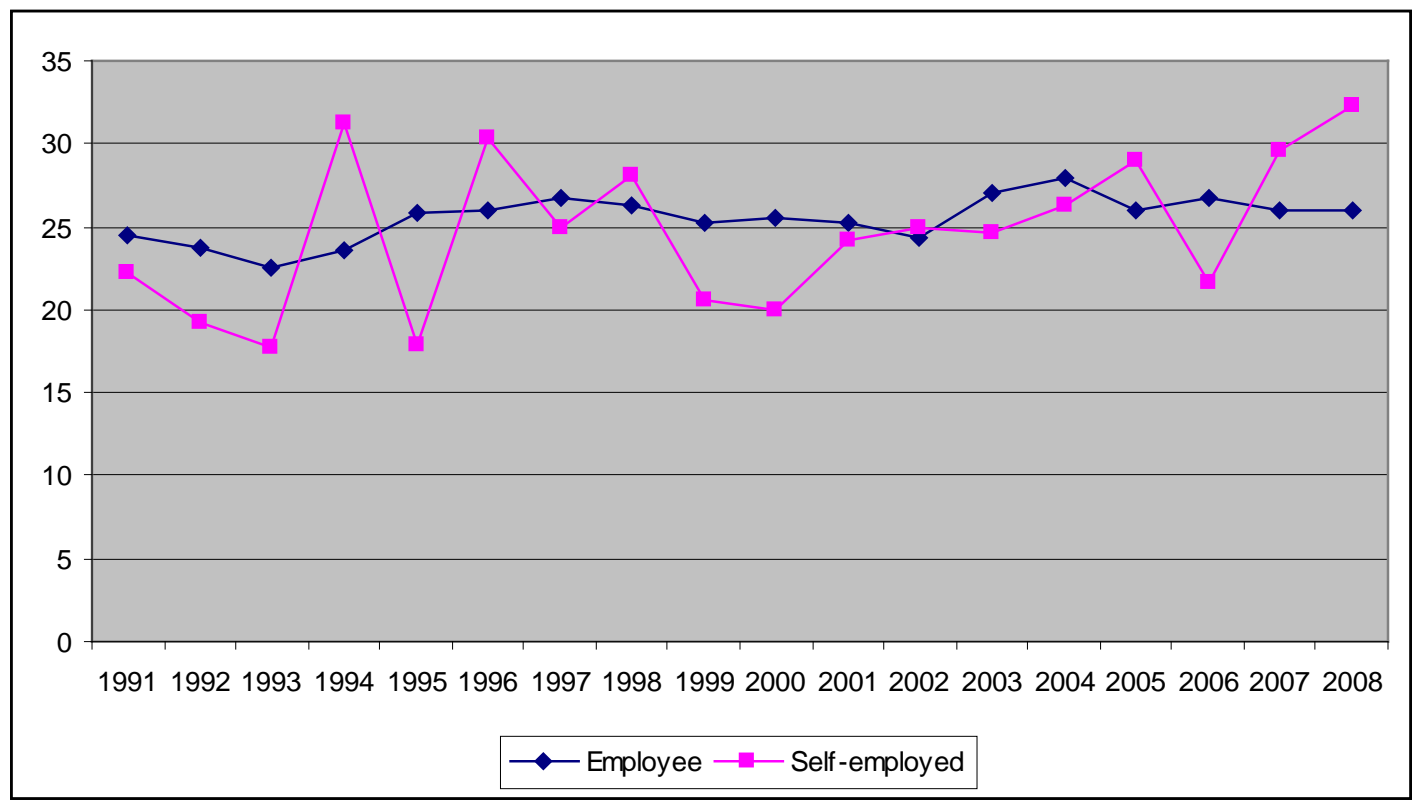

Proposition 1: second job hours among the self-employed

The empirical analysis specifically seeks to test three propositions. With respect to proposition 1 - self-employed second job holders are likely to work longer hours when moonlighting than employees - the evidence from the BHPS supports the notion that self-employed men are more likely to work longer second job hours than employees, and self-employed women. Self-employed men moonlight very long hours, supporting the notion that self-employed men are committed to the venture, rather than choosing self-employment to balance working hours with other activities. It also suggests that self-employed men have little leeway to increase their hours in their self-employment or by taking on additional moonlighting hours. Indeed, the length of 'main job' and second job working hours found in this analysis suggests that self-employed men are to capacity in terms of time worked, i.e. there is little further opportunity to increase hours. 
In contrast, Figure 2 indicates self-employed women worked fewer second job hours per month than their employed counterparts, although second job working hours for self-employed women fluctuated annually, often considerably. This offers initial indication of shorter work-time among self-employed women, even those moonlighting, perhaps evident of non-work commitments to the household (Hundley, 2001; Schmid, 2010). The volatility of annual hours worked in a second job by selfemployed women raises a wider question about the reasons for these fluctuations.

\section{Proposition 2: gendered patterns of second job holding}

Tables 1 and 2 summarize the Tobit models. The models indicate that selfemployed women who moonlight are more likely to be highly qualified, in professional occupations, and working at home. Consistent with proposition 2 women are more likely than men to seek out self-employment to generate greater flexibility in work (including hours, location) because of non-work related tasks, but for some women this route into self-employment necessitates second job holding these factors, rather than difficulties in paying for housing, appear to be important determinants of second job holding among self-employed women. On average, 45.1\% of self-employed women report working at home or using home as a base for their business. Rates are lower among men (39.0\%). These results could be indicative of women in highly skilled occupations retaining links with former employers or clients through secondary employment (Mason et al, 2011). Working at home suggests that the capitalization of self-employment is insufficient to fund separate premises for the business, and this is more common for women. Again, this would be consistent with the tendency for the self-employed to moonlight because of lack of income generated from the business (Hundley, 2001). 
Table 1: Random-effects Tobit regression for men

\begin{tabular}{|c|c|c|c|c|}
\hline \multirow[t]{2}{*}{ J2hours } & \multicolumn{2}{|c|}{ Employed } & \multicolumn{2}{|c|}{ Self-employed } \\
\hline & Coefficient & S.E. & Coefficient & S.E. \\
\hline Mortgaged & -0.160 & 0.110 & $-0.684^{* *}$ & 0.282 \\
\hline Difficulty pay & $0.442 * * *$ & 0.170 & $0.883^{* *}$ & 0.417 \\
\hline Income & $-0.024 * * *$ & 0.004 & -0.006 & 0.005 \\
\hline No. of Children & 0.087 & 0.059 & $-0.340 * *$ & 0.143 \\
\hline Married & 0.167 & 0.148 & 0.014 & 0.368 \\
\hline Good health & $-0.233 * *$ & 0.113 & -0.050 & 0.294 \\
\hline Age & 0.027 & 0.031 & $0.225^{* *}$ & 0.090 \\
\hline Age $^{2} / 100$ & -0.032 & 0.038 & $-0.296 * * *$ & 0.105 \\
\hline \multicolumn{5}{|c|}{ Highest qualification (ISCED): reference is no qualifications } \\
\hline Master/Doctoral degree & $2.206 * * *$ & 0.371 & $3.856 * * *$ & 1.095 \\
\hline Bachelor degree & $0.473^{* *}$ & 0.229 & $2.825 * * *$ & 0.646 \\
\hline Post-secondary (A-level) & $0.680 * * *$ & 0.169 & $1.428 * * *$ & 0.456 \\
\hline Upper secondary (GCSE) & $0.709 * * *$ & 0.166 & $1.398 * * *$ & 0.431 \\
\hline \multicolumn{5}{|c|}{ Occupation (SOC): reference is elementary occupations } \\
\hline Managers & $-0.438 * *$ & 0.221 & 0.062 & 0.607 \\
\hline Professionals & 0.039 & 0.256 & -0.467 & 0.745 \\
\hline Technical & -0.295 & 0.238 & -0.470 & 0.715 \\
\hline Administrative & -0.010 & 0.233 & -1.306 & 1.647 \\
\hline Skilled trades & $-0.371 *$ & 0.212 & $-0.997 *$ & 0.601 \\
\hline Services & 0.338 & 0.255 & $4.114^{* * *}$ & 1.184 \\
\hline Sales & 0.167 & 0.262 & 0.324 & 0.915 \\
\hline Operatives & $-0.387 *$ & 0.217 & -0.982 & 0.728 \\
\hline \multicolumn{5}{|c|}{ Work location (employed): reference is employer premises } \\
\hline Home & 0.624 & 0.423 & - & - \\
\hline Driving & $0.461^{* * *}$ & 0.150 & - & - \\
\hline Multi-site & 0.245 & 0.155 & - & - \\
\hline \multicolumn{5}{|c|}{ Work location (self-employed): reference is business premises } \\
\hline Home & - & - & 0.543 & 0.459 \\
\hline From home & - & - & $0.901 * * *$ & 0.323 \\
\hline Van/stall & - & - & -0.213 & 0.737 \\
\hline Client premises & - & - & 0.208 & 0.324 \\
\hline \multicolumn{5}{|c|}{ Partner employment variables } \\
\hline Partner working & -0.067 & 0.178 & 0.338 & 0.386 \\
\hline Partner working hrs & -0.000 & 0.006 & -0.001 & 0.011 \\
\hline Partner income & 0.057 & 0.093 & $0.287^{*}$ & 0.172 \\
\hline Constants & $1.546 * *$ & 0.644 & -2.476 & 2.062 \\
\hline Year dummies & Yes & & Yes & \\
\hline Regional dummies & Yes & & Yes & \\
\hline Sigma_u & 5.531 & 0.065 & 6.955 & 0.166 \\
\hline Sigma_e & 8.585 & 0.028 & 9.719 & 0.073 \\
\hline Rho & 0.293 & 0.005 & 0.339 & 0.019 \\
\hline Wald chi2 & 243.36 & & 145.59 & \\
\hline Log likelihood & $-205,026.85$ & & $-43,559.525$ & \\
\hline Observations & 55,997 & & 11,439 & \\
\hline No of individuals & 9,894 & & 2,607 & \\
\hline Obs per ind. Min & 1 & & 1 & \\
\hline Obs per ind. avg & 5.7 & & 4.4 & \\
\hline Obs per ind. max & 17 & & 17 & \\
\hline
\end{tabular}


Table 2: Random-effects Tobit regression for women

\begin{tabular}{|c|c|c|c|c|}
\hline \multirow[t]{2}{*}{ J2hours } & \multicolumn{2}{|c|}{ Employed } & \multicolumn{2}{|c|}{ Self-employed } \\
\hline & Coefficient & S.E. & Coefficient & S.E. \\
\hline Mortgaged & $0.321^{* * *}$ & 0.106 & 0.485 & 0.393 \\
\hline Difficulty pay & $0.696 * * *$ & 0.161 & 0.975 & 0.615 \\
\hline Income & $-0.034 * * *$ & 0.004 & $-0.018 *$ & 0.010 \\
\hline No. of Children & 0.011 & 0.058 & 0.085 & 0.210 \\
\hline Married & $-0.339 * *$ & 0.142 & -0.248 & 0.521 \\
\hline Good health & -0.066 & 0.106 & 0.198 & 0.408 \\
\hline Age & $0.049 *$ & 0.030 & -0.118 & 0.128 \\
\hline $\mathrm{Age}^{2} / 100$ & -0.060 & 0.038 & 0.101 & 0.152 \\
\hline \multicolumn{5}{|c|}{ Highest qualification (ISCED): reference is no qualifications } \\
\hline Master/Doctoral degree & $1.042 * * *$ & 0.384 & $2.420^{* *}$ & 1.208 \\
\hline Bachelor degree & $0.714 * * *$ & 0.208 & $1.530^{* *}$ & 0.675 \\
\hline Post-secondary (A-level) & $0.317 * * *$ & 0.163 & 0.847 & 0.558 \\
\hline Upper secondary (GCSE) & $0.199 * *$ & 0.148 & -0.270 & 0.517 \\
\hline \multicolumn{5}{|c|}{ Occupation (SOC): reference is elementary occupations } \\
\hline Managers & $-1.664 * * *$ & 0.233 & -0.124 & 0.763 \\
\hline Professionals & $-1.420 * * *$ & 0.252 & $1.944^{* *}$ & 0.913 \\
\hline Technical & $-0.853^{* * *}$ & 0.229 & 0.216 & 0.860 \\
\hline Administrative & $-1.168^{* * *}$ & 0.202 & -0.350 & 0.977 \\
\hline Skilled trades & $-2.102 * * *$ & 0.391 & 0.565 & 1.134 \\
\hline Services & -0.291 & 0.201 & 0.434 & 0.817 \\
\hline Sales & $-0.979 * * *$ & 0.219 & -1.358 & 1.057 \\
\hline Operatives & $-1.158^{* * *}$ & 0.314 & 0.824 & 1.676 \\
\hline \multicolumn{5}{|c|}{ Work location (employed): reference is employer premises } \\
\hline Home & 0.610 & 0.379 & - & - \\
\hline Driving & 0.151 & 0.234 & - & - \\
\hline Multi-site & 0.223 & 0.206 & - & - \\
\hline \multicolumn{5}{|c|}{ Work location (self-employed): reference is business premises } \\
\hline Home & - & - & $1.012^{* *}$ & 0.486 \\
\hline From home & - & - & 0.234 & 0.512 \\
\hline Van/stall & - & - & -0.250 & 1.673 \\
\hline Client premises & - & - & $1.218^{* *}$ & 0.528 \\
\hline \multicolumn{5}{|c|}{ Partner employment variables } \\
\hline Partner working & -0.014 & 0.174 & $-1.249 * *$ & 0.594 \\
\hline Partner working hrs & 0.001 & 0.004 & $0.0162 *$ & 0.010 \\
\hline Partner income & 0.013 & 0.042 & -0.109 & 0.104 \\
\hline Constants & $2.165^{* * *}$ & 0.620 & $4.882^{*}$ & 2.972 \\
\hline Year dummies & Yes & & Yes & \\
\hline Regional dummies & Yes & & Yes & \\
\hline Sigma_u & 4.761 & 0.058 & 4.259 & 0.259 \\
\hline Sigma_e & 8.925 & 0.028 & 9.523 & 0.118 \\
\hline Rho & 0.222 & 0.005 & 0.167 & 0.018 \\
\hline Wald chi2 & 375.47 & & 104.04 & \\
\hline Log likelihood & $-22,0262.7$ & & $-16,470.498$ & \\
\hline Observations & 59,822 & & 4,405 & \\
\hline No of individuals & 10,539 & & 1,229 & \\
\hline Obs per ind. Min & 1 & & 1 & \\
\hline Obs per ind. avg & 5.7 & & 3.6 & \\
\hline Obs per ind. max & 17 & & 17 & \\
\hline
\end{tabular}


Self-employed men in caring, leisure and other service occupations are more likely to moonlight. This result could reflect employment in occupations where workers are categorized as self-employed 'independent contractors', supporting the notion of a casualization of the workforce through transfer from employment contracts to self-employment (Raess and Burgoon, 2015, 95-6). Again, this is consistent with moonlighting due to insufficient income from self-employment, because the primary rationale for such casualization is to make these labour costs more flexible for the contracting business. Approximately 9.8\% of self-employed men in the BHPS sample, on average, reported this nature of self-employment. Meanwhile, employed men holding second jobs are more likely to drive for work, indicative of logistics, taxi driving, and certain sales occupations.

\section{Proposition 3: financial hardship and housing costs}

With respect to proposition 3 - housing costs are likely to be positively and significantly correlated with second job holding for both the employed and selfemployed - the models indicate second job holding is positively correlated with difficulties in paying for housing. This finding is highly significant for all men and for women employees. Second job holding therefore is an important income stream for those who are facing real constraints on income from their main jobs, and as a result may not have sufficient funds to cover housing costs from their principle source of income. Self-employed men facing these difficulties are noticeably more likely than their employed gender equivalent to moonlight, and employed women are more likely than their male counterparts to take on a second job. For all three groups the relationship between second job holding and difficulties in paying for housing is strong and significant. 
The results between having a mortgage and moonlighting are mixed. There is no significant relationship for employed men and self-employed women. However, there is a significantly negative relationship between moonlighting and having a mortgage for self-employed men and a significant positive relationship for employed women. Self-employed men are much more likely to take a second job if they have difficulty paying housing costs, but are much less likely to do so when holding a mortgage.

These results support a broad finding that facing housing payment difficulties is likely to result in second job holding to supplement incomes, and hence cover payment pressures. Consistent with these results, lower annual labour income increases the chance for moonlighting. This impact is significant for employed men, and employed and self-employed women, suggesting financial pressure is at least partly relevant for self-employed women, even though this may not go as far as financial hardship. The contrasting results between financial hardship and mortgageholding and second job holding between self-employed men and women indicate a different effect by gender. Moonlighting self-employed women’s partners are less likely to be in work. Where partners are working, though, their working hours are positively associated with second job holding among self-employed women. This may offer evidence of a potential split between women who hold a second job through financial necessity as their partner is not working, and those that hold second jobs for other reasons, which we outline below. Overall, these results suggest that financial compunction is a key driver of second job holding among men and women employees and self-employed men, whereas while income may act as a driver among selfemployed women, other factors than financial hardship appear to act as primary drivers. 


\section{Control variables}

Exploring the demographic variables, age has a significant effect for selfemployed men and employed women, suggesting that as they become older they are more likely to moonlight. Married women employees are less likely to take on a second job. Results for men are statistically insignificant. Meanwhile among the selfemployed, men with dependent children are significantly less likely to take a second job. Although a positive association is found between the presence of dependent children and moonlighting among women, it is statistically insignificant. These results suggest that for male entrepreneurs having children is a disincentive to moonlighting.

The regional dummies are mostly insignificant, but with some important exceptions. Self-employed men in the East and South East are more likely to be multiple job holders compared to their counterparts elsewhere. This probably reflects the higher costs of living and in particular housing, in these regions of the UK, rendering dual job holding a financial necessity for some workers. As a result, barriers to self-employment appear higher in the South East for men (Morrison, 2006). In Northern Ireland, male employees are more likely to moonlight, but women employees are less likely to take a second job. In contrast, in the South East, women employees are more likely to moonlight, again likely evidencing financial necessity.

\section{Discussion and conclusion}

This paper investigates second job holding by the self-employed and employees in the UK using panel data from the British Household Panel Survey, 1991-2009. The longitudinal nature of the analysis, and the breadth of data on which it is based, provide a robust empirical basis for analysis. Table 3 summarizes the 
findings of the analysis with respect to the propositions developed in the paper. The findings support proposition 1 for self-employed men, who work longer than employees when moonlighting, but not for self-employed women whose patterns of self-employment may be more constrained by their household contribution (Hundley, 2001; Schmid, 2010; Wheatley and Wu, 2014). This suggests that the motivations for self-employment vary by gender. Proposition 2 is upheld. Self-employed women work shorter hours, homework, and are less likely to moonlight where their partner is in work. Finally, proposition 3 is upheld, but is particularly pronounced for selfemployed men who are more likely to moonlight because they have difficulty paying housing costs. The results for mortgage payments are mixed. Self-employed men are much less likely to moonlight if they have a mortgage, but employed women are much more likely to take on a second job if they have a mortgage. For employed men and self-employed women, there is no relationship between moonlighting and having a mortgage. These results suggest women employees address difficulty paying for housing by taking on a second job, but self-employed men do so by working longer hours in self-employment. Although income is negatively associated with second job holding among self-employed women, housing costs are not significant. Second job holding in this case may be more indicative of lower capitalization (consistent with Mason et al, 2011), and income, associated with many women-owned businesses which requires work 'on the side' to build client bases and return required income.

The contrast between difficulties in paying for housing and mortgage-holding, further, indicate a distinction between renting and house ownership (as indicated by mortgage payment). The findings indicate that self-employed individuals renting housing work longer hours in a second job, whereas those with a mortgage are much less likely to moonlight even though they work the longest hours. This implies that 
Table 3: Assessment of Propositions

\begin{tabular}{|l|l|}
\hline $\begin{array}{l}\text { 1: Self-employed second job holders are likely to } \\
\text { work longer hours when moonlighting than } \\
\text { employees. }\end{array}$ & $\begin{array}{l}\text { This proposition is supported for self-employed } \\
\text { men, who worked more average hours per month } \\
\text { than their employed male counterparts for every } \\
\text { year but one between } 1991 \text { and 2009. } \\
\text { This proposition is not upheld for self-employed } \\
\text { women. }\end{array}$ \\
\hline $\begin{array}{l}\text { 2: Women are more likely than men to seek out } \\
\text { self-employment to generate greater flexibility in } \\
\text { work (including hours, location) because of non- } \\
\text { work related tasks, but for some women this route } \\
\text { into self-employment necessitates second job } \\
\text { holding. }\end{array}$ & $\begin{array}{l}\text { This proposition is upheld. Self-employment } \\
\text { among women is associated with shorter hours, } \\
\text { homeworking, and these women are less likely to } \\
\text { take on second job hours if their partner is } \\
\text { working. However, although a positive } \\
\text { association is present between moonlighting and } \\
\text { having children for self-employed women it is not } \\
\text { significant. }\end{array}$ \\
\hline $\begin{array}{l}\text { 3: Housing costs are likely to be positively and } \\
\text { significantly correlated with second job holding } \\
\text { for both the employed and self-employed. }\end{array}$ & $\begin{array}{l}\text { This is upheld and the effects of difficulties in } \\
\text { paying a mortgage are particularly significant for } \\
\text { self-employed men, indicating that paying } \\
\text { housing costs is a primary driver for the self- } \\
\text { employed to moonlight. Second job holding } \\
\text { among self-employed women may be more } \\
\text { indicative of low capitalization, and income, } \\
\text { associated with many women-owned businesses. }\end{array}$ \\
\hline
\end{tabular}

self-employed men 'hold on to their venture' by working longer hours. Moonlighting employees, in contrast, do so to cover the costs of renting by supplementing low-pay from their main job.

There are therefore different dynamics associated with renting and paying a mortgage and how this interacts with whether an individual is seeking to 'hold on' to a venture, or is supplementing low or inconsistent pay from either a main job or from contracting. Table 4 considers these dynamics by conceiving of two forms of employment activity for individuals who moonlight. The first is entrepreneurs who moonlight to continue their self-employment as their main occupation. In essence, these individuals are 'holding on' to a venture that does not generate sufficient financial return by moonlighting. The second is individuals who are insufficiently paid and also face uncertainty in their main occupation. For employees, the main job 
is not sufficiently well paid to cover housing costs, and by inference other living costs.

For the self-employed, their venture does not provide sufficient return or, for example, if they have been re-employed as a contractor, the pay is uncertain and volatile, so requiring a second job to smooth out variations in pay. Table 4 considers these scenarios and articulates a clear difference between renters and mortgage payers.

Table 4: Dynamics of renting and mortgage holding for self-employed and employed

\begin{tabular}{|c|c|c|}
\hline Renting & $\begin{array}{l}\text { Can vary rents, so less } \\
\text { incentive to moonlight to } \\
\text { cover housing costs. } \\
\text { Likely to have little } \\
\text { disposable income, } \\
\text { because this would be } \\
\text { used to sustain the } \\
\text { venture. }\end{array}$ & $\begin{array}{l}\text { - Second job holding to } \\
\text { cover housing and living } \\
\text { costs, even when rent can } \\
\text { be reduced by changing } \\
\text { housing. This implies } \\
\text { low paid main jobs or } \\
\text { contracting are not viable } \\
\text { employment options } \\
\text { without moonlighting. }\end{array}$ \\
\hline \multirow[t]{2}{*}{ Mortgage } & $\begin{array}{l}\text { - Second job holding } \\
\text { focused on keeping } \\
\text { business going. } \\
\text { Second job hours more } \\
\text { likely to sustain venture, } \\
\text { but may also cover living } \\
\text { costs and/or service } \\
\text { mortgage. }\end{array}$ & $\begin{array}{l}\text { Second job holding to } \\
\text { protect mortgage and } \\
\text { asset. } \\
\text { - Mortgage payments and } \\
\text { asset at risk. }\end{array}$ \\
\hline & Holding on to a venture & $\begin{array}{l}\text { henting low } \\
\text { ctable pay }\end{array}$ \\
\hline
\end{tabular}

Overall, the key finding for this paper is that individuals will stay in selfemployment through second job holding even when their business is not making the financial returns that would justify continuation. This suggests that among the selfemployed: (1) second jobs supplement incomes either to help build a business or to smooth out uncertain and volatile incomes, and/or; (2) the amenity value of selfemployment is greater than the value of being employed, even if the financial benefits are insufficient to support self-employment without supplementary moonlighting. In the prior case, this may be after the individual has moved from employment as the primary job, or it may be following on from a period of extended self-employment. Regardless, this decision is made to supplement entrepreneurial income with paid 
wages. Where building a business, the motivation for taking on a second job would be future anticipation of improved returns from self-employment. Should anticipated future returns not be forthcoming, however, this may drive exit from selfemployment. In these instances, moonlighting will delay exit. Where driven by amenity value, the likelihood of experiencing difficulties in paying for housing may in fact be greater because individuals are less concerned with the financial returns from running their own business than with the amenity value of self-employment, and retain the links that this provides to the corporate sphere during self-employment. Motivations to stay self-employed thus extend beyond financial returns to qualitative benefits, and effects, including perceived greater autonomy and satisfaction derived from the business venture (Blanchflower, 2000; Eckersley, 2007) and/or work-life balance benefits. These individuals may consciously accept they are unlikely to ever generate sufficient income from their business to cover living costs, and so seek a permanent or at least longer-term job to supplement their earnings. In these cases, second job holding is likely to be a long-term, if not permanent, feature of selfemployment.

This 'hybrid entrepreneurship' raises questions about the motivations to stay in self-employment if a second job is needed to generate income to cover living costs. A purely economic justification would suggest that if returns from self-employment are less than those from paid employment, the rational decision would be to close the business. The findings in this paper indicate that, in contrast to this logic, entrepreneurs take on a second job and continue in self-employment. Previous accounts of 'hybrid entrepreneurship' focus on individuals who hold on to paid employment whilst starting and running a business 'on the side' or out of working hours (Folta et al. 2010). In these cases, there is a transition into self-employment 
from employment, and so moonlighting is often a temporary arrangement. The analysis presented, though, indicates an opposite dynamic, of moving from selfemployment to hybrid entrepreneurship.

Although the self-employed may hold second jobs because they cannot identify superior single job incomes, the logic underpinning the empirical analysis indicates this is unlikely, as the rationale for taking on a second job is that such returns are not forthcoming from the primary business. This possibility is further challenged by our finding that self-employed moonlighters on the whole have higherlevel qualifications, and work in highly skilled occupations (among women). For these entrepreneurs, a rational decision would be to exit self-employment to take up higher paid employment thanks to their higher human capital. This indicates that entrepreneurs, when faced with financial difficulties, may be willing to forgo leisure time by taking on a second job and so extending working hours. Accepting reduced returns from self-employment over time, combined with sacrificing leisure time, suggests a complex relationship between the lifestyle gains from self-employment and the extensive hours of labour which may be required to maintain self-employment.

These findings have a number of important implications. Firstly, some entrepreneurs hold a second job regardless of wider economic conditions. As Figures 1 and 2 highlight, second job hours were higher for the self-employed in every year for men and fluctuated year-on-year for women. The empirical analysis indicates that this is an ongoing trend, and so is endemic to self-employment, regardless of the wider macroeconomic environment (Parker et al, 2012). Second, important gender distinctions are present in the drivers of second job holding among the self-employed. This has important implications for our understanding of the nature of entrepreneurial activity among men and women, and the different challenges the self-employed 
encounter. Thirdly, moonlighting by the self-employed will skew national data on economic activity. The self-employed may take on a second job as an alternative to closing a business. Whether second job holding is temporary or permanent, the effect is to sustain self-employment as the main occupation thus avoiding entrepreneurial exit. This suggests greater firm resilience for businesses owned by entrepreneurs who take on a second job. It also suggests that moonlighting suppresses firm closures, affecting calculations of the net start-up rate and stock of businesses. Finally, the analysis indicates that the relationship between self-employment and employment is more intertwined and ambiguous than it might appear, and that the dynamics of entrepreneurial exit are 'complicated' by the intersections of these types of work (Bruce and Schuetze, 2008; Wennberg and DeTienne, 2014). Results indicate that at any one time a sub-set of the self-employed moonlight. Hybrid entrepreneurship appears to be standard practice for many self-employed, and moonlighting provides a means of staying in as well as entering into self-employment.

\section{Acknowledgements}

The authors would like to thank the editor and the anonymous referee for their comments on the earlier versions of this article. We are grateful to the UK Data Archive at Essex University for providing access to the British Household Panel Survey (BHPS).

\section{References}

Alden, J. (1982). A comparative analysis of moonlighting in Great Britain and the USA. Industrial Relations Journal, 13(2), 21-31.

Amuedo-Dorantes, C., Kimmel J. (2009). Moonlighting over the business cycle. Economic Inquiry, 47(4), 754-765. 
Barton, H. (2000). Does entrepreneurship pay? An empirical analysis of the returns to self-employment. Journal of Political Economy, 108(3), 604-631.

Benz, M. (2009). Entrepreneurship as a non-profit-seeking activity. International Entrepreneurship and Management Journal, 5(1), 23-44.

Bell, D., Hart, R., Wright, R. (1997). Multiple job-holding as a 'hedge’ against unemployment, CEPR Discussion Paper, No. 1626.

Blanchflower, D. (2000). Self-employment in OECD countries. Labour Economics, 7(5), 471-505.

Brown, S., Taylor, K., Price, S. (2005). Debt and distress: evaluating the psychological cost of credit. Journal of Economic Psychology, 26(5), 642-663.

British Household Panel Survey [computer file], ESRC Research Centre on Microsocial Change. -Colchester: The Data Archive [distributor], 2009. Data files and associated documentation.

Bruce, D., Schuetze, H. (2008). The labour market consequences of experience in self-employment. Labour Economics, 11, 5, 575-598.

Burke, A., Fitzroy, F., Nolan, M. (2008). What makes a die-hard entrepreneur? Beyond the 'employee of entrepreneur' dichotomy. Small Business Economics, 31(2), 93-115.

Ceritoglu, E. (2013). The Impact of Labour Income Risk on household Saving Decision in Turkey, Review of Economics of the Household, 11(1), 109-129

Conway, K., Kimmel, J. (1998). Male labour supply estimates and the decision to moonlight. Labour Economics, 5(2), 135-166. 
Cowling, M., Liu, W., Ledger, A. (2012). Small business financing in the UK before and during the current financial crisis. International Small Business Journal, 30(7), 778-800.

Dawson, C., Henley, A. (2013). Over-optimism and entry and exit from selfemployment. International Small Business Journal, 31(8), 938-954.

Dawson, C., Henley, A. (2012). “Push” versus “pull” entrepreneurship: an ambiguous distinction? International Journal of Entrepreneurial Behavior \& Research, 18(6), 697-719.

Deidda, M. (2015). Economic Hardship, Housing Cost Burden and Tenure Status: Evidence from EU-SILC. Journal of Family and Economic Issues, 36(4), 531-556.

Dickey, H., Watson, V., Zangelidis, A. (2011). Is it all about money? An examination of the motives behind moonlighting. Applied Economics, 43(26), 3767 - 3774.

Drew, E. (1998). Changing family forms and the allocation of caring. In, E. Drew, R. Emerek and E. Mahon (eds.) Women, work and the family in Europe. London: Routledge, 27-35.

Eckersley, R. (2007). The Politics of Happiness. Living Now, 93, 6-7.

Fenwick, T. (2006). Contradictions in portfolio careers: work design and client relations. Career Development International, 11(1), 65-79.

Flandez, R. (2009). Entrepreneurs take second jobs to stay afloat. The Wall Street Journal, June $16^{\text {th }} 2009$.

Folta, T., Delmar, F., Wennberg, K. (2010). Hybrid entrepreneurship. Management Science, 56(2), 253-269.

Fraser, J., Gold, M. (2001). 'Portfolio Workers': Autonomy and Control amongst Freelance Translators. Work, Employment and Society, 15(4), 679-697. 
Green, A., Livanos, I. (2015). Involuntary non-standard employment and the economic crisis: regional insights from the UK. Regional Studies, 49(7), 1223-1235.

Guariglia A., Kim B. Y. (2004). Earnings uncertainty, precautionary saving, and moonlighting in Russia, Journal of Population Economics, 17(2), 289-310.

Henley, A. (2007). Entrepreneurial aspiration and transition into self-employment: evidence from British longitudinal data. Entrepreneurship \& Regional Development, 19(3), 253-280.

Hundley, G. (2001). Why women earn less than men in self-employment. Journal of Labour Research, 22(4), 817-829.

Hytti, U. (2010) Contextualizing entrepreneurship in the boundaryless career. Gender in Management: An International Journal, 25(1), 64-81.

Kalleberg, A.L., Nesheim, T., Olsen, K.M. (2009). Is participation good or bad for workers? Acta Sociologica, 52(2), 99-116.

Kimmel, J., Conway, K. (2001). Who moonlights and why? Evidence from the SIPP. Industrial Relations, 40(1), 89-120.

Labour Force Survey (2009), Office for National Statistics. Social Survey Division, Northern Ireland Statistics and Research Agency. Central Survey Unit. (2014). Quarterly Labour Force Survey, October - December, 2009. [data collection]. 2nd Edition. UK Data Service. SN: 6404, http://dx.doi.org/10.5255/UKDA-SN-6404-2.

Lee, S., McCann, D., Messenger, J. (2007). Working Time around the World: Trends in Working Hours, Laws, and Policies in a Global Comparative Perspective. Oxon, UK: Routledge. 
Lewis, J. and M. Campbell (2008), 'What's in a Name? "Work and Family” or "Work and Life” Balance Policies in the UK since 1997 and the Implications for the Pursuit of Gender Equality’, Social Policy and Administration, 42, 5, 524-541.

Livanos, I., Zangelidis, A. (2012). Multiple job-holding among male workers in Greece. Regional Studies, 46(1), 119-135.

Lundborg, P. (1995). Job amenity and the incidence of double work, Journal of Economic Behaviour and Organization, 26(2), 273-287.

Mallon, M., Cohen, L. (2001). Time for a change? Women’s accounts of the move from organizational careers to self-employment. British Journal of Management, 12, 217-230.

Mason, C., Carter, S., Tagg, S. (2011). Invisible Businesses: The Characteristics of Home-based Businesses in the United Kingdom. Regional Studies, 45(5), 625-39.

Meier, S., Stutzer, A. (2006). Is volunteering rewarding in itself? Center for Behavioral Economics and Decision-Making, Federal Reserve Bank of Boston.

Morrison, A. (2006). A contextualization of entrepreneurship. International Journal of Entrepreneurial Behaviour and Research, 12(4), 192-209.

ONS (2014), Self-employed workers in the UK [online]. Retrieved May 2015 from http://www.ons.gov.uk/ons/dcp171776_374941.pdf.

Panos, G., Pouliakas, K., Zangelidis, A. (2009). The inter-related dynamics of dual job holding, human capital and occupational choice. IZA Discussion paper series, No. 4437.

Parker, S., Congregado, E., Golpe, A. (2012). Is entrepreneurship a leading or lagging indicator of the business cycle? Evidence from UK self-employment data. International Small Business Journal, 30(7), 736-753. 
Partridge, M. (2002). Moonlighting in a High Growth Economy: Evidence from U.S. State-Level Data. Growth and Change, 33(4), 424-452.

Paxson, C., Sicherman, N. (1996). The dynamics of dual job holding. Journal of Labor Economics, 14(3), 357-393.

Perlman, R. (1966). Observations on overtime and moonlighting. Southern Economic Journal, 33(2), 237-244.

Raess, D., Burgoon, B. (2015). Flexible Work and Immigration in Europe. British Journal of Industrial Relations, 53(1), 94-111.

Renna, F. (2006). Moonlighting and Overtime: A Cross-Country Analysis. Journal of Labor Research, 27(4), 575-591.

Schmid, G. (2010). Non-Standard Employment and Labour Force Participation: A Comparative View of the Recent Development in Europe. IZA Discussion Paper No. 5087.

Shishko, R., Rostker, B. (1976). The economics of multiple job holding. American Economic Review, 66(3), 298-308.

Stanworth, C., Stanworth, J. (1995). The self-employed without employees autonomous or atypical? Industrial Relations Journal, 26(3), 221-229.

Stone, M.E. (2006). What is housing affordability? The case for the residual income approach. Housing Policy Debate, 17(1), 151-184.

Wennberg, K., DeTienne, D. (2014). What do we really mean when we talk about 'exit'? A critical review of research on entrepreneurial exit. International Small Business Journal, 32(1), 4-16. 
Wheatley, D., Wu, Z (2014). Dual Careers, Time-Use, and Satisfaction Levels: Evidence from the British Household Panel Survey. Industrial Relations Journal, 45(5), 443-464.

Wu, Z., Baimbridge, M., and Zhu, Y., (2009) Multiple Job Holding in the UK:

Evidence from the British Household Panel Survey. Applied Economics, 41 (21), 2751-2766

\section{Appendix: The Model}

Moonlighting models based on the standard labour-leisure utility approach (e.g. Perlman, 1966; Shishko and Rostker, 1976; Conway and Kimmel, 1998; Partridge, 2002) assume that a worker maximizes a utility function that has consumption and leisure as arguments subject to time and budget constraints. Their objective is to identify the factors that influence the worker to take a second job. Our stylized model blends the main job hour constrained model, with the heterogeneous job model, including financial hardship. The model, further, distinguishes the second job labour supply of the self-employed and employees.

Assume the representative agent maximizes the following utility function:

$$
U=U\left(C, h_{1}, h_{2}, L, Z\right)
$$

Where $C$ is consumption, $L$ is leisure, $\mathrm{Z}$ is a vector of personal attributes [such as age, gender, education, number of children], $h_{1}$ is the hours of work in the primary job, $h_{2}$ is the hours of work in the second job. Note that both enter the utility function because labour supplied to different jobs may not be equivalent (see Conway and Kimmel, 1998). This last feature characterizes the heterogeneous job model. Notice that $U_{C}>0, U_{1}<0, U_{2}<0, U_{L}>0$, where $U_{1}, U_{2}$ denote the partial derivative of utility with respect to $h_{1}, h_{2}$, respectively. 
The constraints of the representative agent are:

$$
\begin{aligned}
& h_{1}+h_{2}+L=T \\
& h_{1} \leq H_{1} \\
& F(M) \leq Y+w_{1} h_{1}+w_{2} h_{2}-C
\end{aligned}
$$

Where $T$ is total amount of time available, $w_{1}$ is primary job wage rate, $w_{2}$ is second job wage rate, $Y$ is non-wage income. The price of consumption is normalized to one. Inequality (3) says that the worker cannot work anymore than $H_{1}$, which is the main feature of the primary job constrained hours model. Inequality (4) states that the worker has to have enough income to cover housing expenditures [rent or mortgage]. Housing expenditures are given by the financial hardship function $F(M), F^{\prime}>0$.

The constrained maximization problem can be rewritten as:

Maximize $U=U\left(C, h_{1}, h_{2}, T-h_{1}-h_{2}, Z\right)$

Subject to $h_{1} \leq H_{1}$

$$
F(M) \leq Y+w_{1} h_{1}+w_{2} h_{2}-C
$$

And $\quad C, h_{1}, h_{2} \geq 0$

The Lagrangian for the problem is:

$$
L=U\left(C, h_{1}, h_{2}, T-h_{1}-h_{2}, Z\right)+\lambda_{1}\left[H_{1}-h_{1}\right]+\lambda_{2}\left[Y+w_{1} h_{1}+w_{2} h_{2}-F(M)-C\right]
$$

Where $\lambda_{1}, \lambda_{2}$ are the Lagrange multipliers. Since the constraints are linear, the KuhnTucker conditions are necessary:

$$
\begin{aligned}
& L_{C}=U_{C}-\lambda_{2} \leq 0, C \geq 0, C L_{C}=0 \\
& L_{1}=U_{1}-U_{L}-\lambda_{1}+w_{1} \lambda_{2} \leq 0, \quad h_{1} \geq 0, \quad h_{1} L_{1}=0 \\
& L_{2}=U_{2}-U_{L}+w_{2} \lambda_{2} \leq 0, \quad h_{2} \geq 0, \quad h_{2} L_{2}=0
\end{aligned}
$$




$$
\begin{aligned}
& L_{\lambda_{1}}=H_{1}-h_{1} \geq 0, \quad \lambda_{1} \geq 0, \quad \lambda_{1} L_{\lambda_{1}}=0 \\
& L_{\lambda_{2}}=Y+w_{1} h_{1}+w_{2} h_{2}-F(M)-C \geq 0, \quad \lambda_{2} \geq 0, \quad \lambda_{2} L_{\lambda_{2}}=0
\end{aligned}
$$

Let us assume that $C, h_{1}, h_{2}>0$. Then, by complementary slackness, we have:

$$
\begin{gathered}
U_{C}=\lambda_{2} \\
U_{1}-U_{L}=\lambda_{1}-w_{1} \lambda_{2} \\
U_{2}-U_{L}=-w_{2} \lambda_{2}
\end{gathered}
$$

The most important characteristic of our model is that we can analyse the selfemployed and the employee cases separately.

\section{The Self-Employed Case}

For the self-employed case we need not to assume the main job hour constrained model, so inequality (3) is not binding, while we assume that inequality (4) that captures financial hardship is binding, as a consequence $\lambda_{1}=0, \lambda_{2}>0$. Therefore we have from (10):

$$
Y+w_{1} h_{1}+w_{2} h_{2}=F(M)+C\left(10^{\prime}\right)
$$

Inserting equation (6') into equations (7') and (8') yields:

$$
\begin{gathered}
\frac{U_{L}-U_{1}}{U_{C}}=w_{1} \\
\frac{U_{L}-U_{2}}{U_{C}}=w_{2}
\end{gathered}
$$

The system formed by equations (10'), (7’) and (8”) determine $C, h_{1}$, and $h_{2}$ simultaneously. The self-employed second job labour supply $h_{2}$ is, thus, a function of personal attributes, wages in the first and second job, financial hardship and non-wage income: 


$$
h_{2}=h_{2}\left[Z, w_{1}, w_{2}, F(M), Y\right]
$$

\section{The Employee Case}

For the employee case we assume the main job constrained hours model, so inequality (3) is binding, we also assume that inequality (4) that captures financial hardship is binding, as a consequence $\lambda_{1}>0, \lambda_{2}>0$, it follows that the worker is working $h_{1}=H_{1}$ fixed hours in the primary job, and equations (10’), and (8”) hold determining the equilibrium values of $\mathrm{C}$ and the employee's second job labour supply $h_{2}$ simultaneously.

The employee second job labour supply $h_{2}$ is a function of personal attributes, second job wages, primary job hours, financial hardship and non-wage income:

$$
h_{2}=h_{2}\left[Z, H_{1}, w_{2}, F(M), Y\right]
$$

\section{Comparison Between Self-Employed and Employee Cases}

Comparison between equations (11) and (12) shows that second job labour supply differs between the self-employed and employees. The main difference between equations (11) and (12) is that $w_{1}$ is an argument of (11), while it is not an argument of (12), in its place (12) has $H_{1}$.

For the employee the comparative statics analysis shows that second job labour supply, $h_{2}$, increases with financial hardship caused by mortgage or rent problems $[M]$, and falls with primary job hours, non-wage income, and it may increase or decrease with second job wage rate: 


$$
\frac{d h_{2}}{d M}>0 ; \frac{d h_{2}}{d H_{1}}<0 ; \frac{d h_{2}}{d Y}>0 ; \frac{d h_{2}}{d w_{2}}>0
$$

For the self-employed second job labour supply, $h_{2}$, also increases with financial hardship caused by mortgage or rent problems $[M]$, and falls with primary job wage rate, non-wage income, and it may increase or decrease with second job wage rate:

$$
\frac{d h_{2}}{d M}>0 ; \frac{d h_{2}}{d w_{1}}<0 ; \frac{d h_{2}}{d Y}>0 ; \frac{d h_{2}}{d w_{2}}>0
$$

The predictions of this model for the employee, given by equation (13), and for the self-employed, given by equation (13’), are tested empirically in this paper using panel data from the BHPS. 